\title{
Chemical Composition of Essential Oil of Amomum xanthioides Wall. ex Baker from Northern Vietnam
}

\author{
Bui B. Thinh 1, * (D), Roman V. Doudkin ${ }^{1,2}$, Vu Q. Thanh ${ }^{3}$ \\ 1 School of Natural Sciences, Far Eastern Federal University, Vladivostok, Russia \\ 2 Botanical Garden-Institute, Far-East Branch, Russian Academy of Sciences, Vladivostok, Russia \\ 3 Vietnam-Russia Tropical Center, Hanoi, Vietnam \\ * Correspondence: buibaothinh9595@gmail.com;
}

Scopus Author ID 57214452856

Received: 2.12.2020; Revised: 29.12.2020; Accepted: 30.12.2020; Published: 3.01.2021

\begin{abstract}
The essential oil from leaves, roots, stems, and fruits of Amomum xanthioides Wall. ex Baker from Northern Vietnam was obtained by hydrodistillation and analyzed by gas chromatography techniques. The yield of the essential oil obtained from leaves, roots, stems, and fruits of A. xanthioides was $0.26 \%, 0.24 \%, 0.19 \%$, and $1.45 \%$ (w/w) by fresh weight, respectively. The composition of the oil samples was compared; 38, 43, 28, and 22 compounds have been identified in the essential oil of leaves, roots, stems, and fruits, accounting for $96.19 \%, 96.61 \%, 98.39 \%$, and $98.12 \%$ of the total oil content, respectively. A high variation among organs for the majority of compounds was shown. $\beta$-elemene (31.71\%), $\delta$-cadinene (10.69\%), germacrene D (9.55\%), bicycloelemene $(8.12 \%)$, and bicyclogermacrene (7.93\%) are the main compounds in leaves, while $\beta$-pinene (29.59\%), terpinen-4-ol $(10.77 \%)$, and $\alpha$-terpinene $(6.96 \%)$ are identified as the main compounds in roots. Stems are characterized by high levels of $\beta$-elemene (29.58\%), spathoulenol (26.89\%), and bicycloelemene $(6.19 \%)$. For fruits, bornyl acetate (37.21\%), camphor (19.48\%), camphene (14.62\%), and limonene (9.64\%) are the main compounds. Overall, this study confirms that changes in the yield, composition, and concentration of the essential oil may be caused by several factors such as environmental conditions and climate at the collection site, the time of collection, and the age and properties of plants. This study also provides new data on the chemical composition of the essential oil from A. xanthioides collected from Northern Vietnam.
\end{abstract}

Keywords: Amomum xanthioides; Zingiberaceae; essential oil composition; volatile oil; gas chromatography.

(C) 2021 by the authors. This article is an open-access article distributed under the terms and conditions of the Creative Commons Attribution (CC BY) license (https://creativecommons.org/licenses/by/4.0/).

\section{Introduction}

Zingiberaceae is one of the essential oil-bearing plant families. Genus Amomum in this family has about 150 species, distributed in tropical Asia, Australia, and islands in the Pacific [1-9]. Vietnam has about 21 species [10]. Species in this genus thrive under the forest canopy, streams, and wet areas. Many species in this genus can be used for medicinal purposes, spices, or to extract essential oils with high economic values [11-14]. They are mainly harvested from natural plants and exported annually to international markets. Some studies on the essential oil of Amomum species in the world have been published [15-23]. These species' essential oil has been proved to have antibacterial, antifungal, and antioxidant properties with a high inhibitory effect [17-27]. In addition, it has been shown to inhibit the growth of cancer cells [28,29]. 
Amomum xanthioides Wall. ex Baker is a species in the genus Amomum. It is about 13 meters tall; Flowers are attached in bunches at plants' foot. Each foot has 3-6 little flower bunches. Each bunch has 4-8 flowers; Fruits are spherical with spines, green and yellow when they are ripe. It lives mainly under the forest canopy and along streams. This species is grown or grows wildly in Northern and Central Vietnam. In addition, it also exists in India, China, Myanmar, Thailand, Laos, and Cambodia [30]. Fruits and seeds of this species are used as medicines, spices, and for the preparation of liqueurs [31-33]. The essential oil composition of A. xanthioides fruits from China has been announced [34,35]. However, there are no prior complete reports of the essential oil from other parts of this species analyzed by gas chromatographic techniques in the world. There are several individual studies on A. xanthioides essential oil from Central Vietnam [36,37]. Studies also noted the effects of geographic, environmental factors, chemical analysis methods as well as extraction methods on the composition and quality of the essential oil [38-40]. Therefore, this article will provide more new data on the essential oil's chemical composition of Amomum xanthioides Wall. ex Baker (leaves, stems, roots, and fruits) from Northern Vietnam was analyzed using gas chromatographic techniques.

\section{Materials and Methods}

\subsection{Plant material.}

Amomum xanthioides Wall. ex Baker (leaves, stems, roots, and fruits) was collected at Na Hang Nature Reserve (Tuyen Quang, Vietnam) in July 2018. We based on Ho's (2000) documents to classify flora samples through morphological characteristics [41]. Fresh plant materials were kept at room temperature $\left(\approx 25^{\circ} \mathrm{C}\right) .1 \mathrm{~kg}$ of each plant material sample was chopped and hydrodistilled with a Clevenger apparatus for 3 hours to produce the essential oil. The essential oil was dried with anhydrous sodium sulfate and placed in amber-colored vials for storage at $4^{\circ} \mathrm{C}$ until it was used for further studies.

\subsection{Gas chromatographic analysis.}

Gas Chromatography (GC) Analysis was performed on an Agilent Technologies HP 7890A Plus equipped with a flame ionization detector (FID) of Agilent Technologies, USA and fitted with HP-5MS chromatographic column with the length of $30 \mathrm{~m}$, inner diameter (ID) $=0.25 \mathrm{~mm}$, and film thickness of $0.25 \mu \mathrm{m} . \mathrm{H}_{2}$ carrier gas $(1 \mathrm{~mL} / \mathrm{min})$. Injector temperature (programmed temperature vaporization-PTV) was $250^{\circ} \mathrm{C}$. Detector temperature was $260^{\circ} \mathrm{C}$. Programmable thermostat temperature: increasing from $60^{\circ} \mathrm{C}(2 \mathrm{mins}$ hold $)$ to $220^{\circ} \mathrm{C}$ at $4^{\circ} \mathrm{C} / \mathrm{min}$. The temperature of $220^{\circ} \mathrm{C}$ was held for 10 minutes. Samples were injected by splitting, and the split ratio was 10:1. The volume injected was $1.0 \mu \mathrm{L}$. Inlet pressure was 6.1 $\mathrm{kPa}$.

HP 7890A Plus Chromatograph of Agilent Technologies (Santa Clara, California, USA) was equipped with a fused silica capillary HP-5MS (30 m x $0.25 \mathrm{~mm}$, film thickness $0.25 \mu \mathrm{m}$ ) and interfaced with a mass spectrometer (HP 5973 MSD) used for the GC-MS analysis, under the same conditions as those used for GC-FID analysis. The conditions were the same as described above with $\mathrm{He}(1 \mathrm{~mL} / \mathrm{min})$ as a carrier gas. The MS conditions were as follows - ionization voltage $70 \mathrm{eV}$; emission current $40 \mathrm{~mA}$; acquisitions scan a mass range of 35-350 amu at a sampling rate of $1.0 \mathrm{scan} / \mathrm{s}$. The chemical compositions of the essential oil were identified based on retention indices (RI) based on a series of n-alkanes, co-injection with 
pure compounds when available (Sigma-Aldrich, St. Louis, MO, USA) or identified known essential oil constituents, MS library search (NIST 17 and Wiley Version 10) and by comparing with MS literature data [42]. The relative amounts (\%) of components were calculated based on the GC peak area (FID response) without using correction factors.

\section{Results and Discussion}

Amomum xanthioides Wall. ex Baker (leaves, stems, roots, and fruits) collected in Tuyen Quang, Vietnam was hydrodistilled to obtain the essential oil. The essential oil with a light-yellow color, lighter weight than water, and a pleasant odor were analyzed by gas chromatography-mass spectrometer (GC-MS) and gas chromatography-flame ionization detector (GC-FID). The A. xanthioides fruit in this study achieved the highest yield of the essential oil (1.45\% in fresh weight) when compared to other plant parts such as leaves $(0.26 \%)$, roots $(0.24 \%)$, and stems $(0.19 \%)$. However, the A. xanthioides fruit's essential oil yield in this study was still lower than previously reported [34,37]. A total of 63 compounds were identified in the essential oil of the parts of A. xanthioides, accounting for $96.19-98.39 \%$ of the total oil content (Table 1). Monoterpene (67.00-97.21\%) is the main group of compounds found in the essential oil of $A$. xanthioides roots and fruits. Sesquiterpene and other groups of compounds account for a low percentage. In contrast, A. xanthioides stems and leaves mainly contain sesquiterpene compounds (83.86-93.66\%). Other compounds account for a low percentage. The characterized compositions of four essential oil samples are $\beta$-pinene (1.23-29.59\%) và $\alpha$ pinene (1.42-5.56\%). The difference in the yield and quality of the essential oil can be explained by the effects of many factors such as chemical analysis method, raw material preparation, collection time, environmental conditions, and climates [38-40]. Along with that, different parts of the same plant species are also factors affecting the yield and quality of the essential oil $[43,44]$.

Table 1. Percentage of chemical constituents of Amomum xanthioides leaves, roots, stems, and fruits essential oil $(\%)$.

\begin{tabular}{|c|c|c|c|c|c|c|}
\hline \multirow{2}{*}{ No. } & \multirow{2}{*}{ Compound name } & \multirow{2}{*}{$\mathbf{R} \mathbf{I}^{\mathbf{a}}$} & \multicolumn{4}{|c|}{ Percentage composition ${ }^{b}$} \\
\hline & & & Leaves & Roots & Stems & Fruits \\
\hline 1 & Tricyclene & 927 & - & 0.11 & - & 0.14 \\
\hline 2 & $\alpha$-Thujene & 930 & 0.11 & 0.42 & - & - \\
\hline 3 & $\alpha$-Pinene & 939 & 3.41 & 5.56 & 1.48 & 1.42 \\
\hline 4 & Camphene & 953 & 0.18 & 3.16 & - & 14.62 \\
\hline 5 & $\beta$-Pinene & 980 & 2.56 & 29.59 & 1.54 & 1.23 \\
\hline 6 & $\beta$-Myrcene & 990 & 0.13 & 1.10 & 0.51 & 3.17 \\
\hline 7 & $\alpha$-Phellandrene & 1006 & 0.24 & 0.13 & - & 0.24 \\
\hline 8 & $\alpha$-Terpinene & 1017 & 0.17 & 6.96 & - & - \\
\hline 9 & o-Cymene & 1024 & 0.16 & - & - & - \\
\hline 10 & Limonene & 1032 & 0.38 & 1.76 & - & 9.64 \\
\hline 11 & 1,8-Cineole & 1036 & - & 0.31 & 0.86 & 2.43 \\
\hline 12 & (E)- $\beta$-Ocimene & 1052 & - & 0.10 & - & - \\
\hline 13 & $\gamma$-Terpinene & 1061 & 0.10 & 1.03 & - & 0.24 \\
\hline 14 & $\alpha$-Terpinolene & 1090 & 0.23 & 1.10 & - & - \\
\hline 15 & Linalool & 1100 & - & - & - & 2.93 \\
\hline 16 & Camphor & 1145 & - & - & - & 19.48 \\
\hline 17 & 2,6-Dimethyl-2,4,6-octatriene & 1147 & 1.44 & - & - & - \\
\hline 18 & Isoborneol & 1156 & - & - & - & 0.18 \\
\hline 19 & Borneol & 1167 & - & - & - & 3.79 \\
\hline 20 & Terpinen-4-ol & 1177 & 0.11 & 10.77 & - & 0.14 \\
\hline 21 & $\alpha$-Terpineol & 1189 & 0.24 & 0.36 & - & 0.13 \\
\hline 22 & Piperitol & 1216 & - & 0.54 & - & - \\
\hline 23 & Fenchyl acetate & 1222 & - & 0.48 & - & - \\
\hline 24 & Bornyl acetate & 1289 & 1.45 & 2.79 & - & 37.21 \\
\hline 25 & 1-Terpineol acetate & 1294 & - & 1.27 & - & -2 \\
\hline
\end{tabular}




\begin{tabular}{|c|c|c|c|c|c|c|}
\hline \multirow{2}{*}{ No. } & \multirow{2}{*}{ Compound name } & \multirow{2}{*}{$\mathbf{R} \mathbf{I}^{\mathbf{a}}$} & \multicolumn{4}{|c|}{ Percentage composition $^{b}$} \\
\hline & & & Leaves & Roots & Stems & Fruits \\
\hline 26 & Bicycloelemene & 1327 & 8.12 & 1.22 & 6.19 & - \\
\hline 27 & $\delta$-Elemene & 1340 & - & 1.13 & - & - \\
\hline 28 & Dodecamethyl-cyclohexasiloxane & 1342 & 0.21 & - & - & - \\
\hline 29 & $\alpha$-Cubebene & 1351 & 0.15 & 0.24 & 0.63 & - \\
\hline 30 & $\alpha$-Copaene & 1377 & 0.55 & - & - & - \\
\hline 31 & $\beta$-Cubebene & 1388 & 1.16 & - & - & - \\
\hline 32 & $\beta$-Elemene & 1391 & 31.71 & 5.39 & 29.58 & - \\
\hline 33 & $\alpha$-Gurjunene & 1412 & 0.13 & - & 0.45 & - \\
\hline 34 & $\beta$-Caryophyllene & 1419 & - & 0.77 & 1.54 & - \\
\hline 35 & $\gamma$-Elemene & 1433 & - & 0.95 & - & - \\
\hline 36 & $\beta$-Gurjunene & 1434 & 0.14 & - & 2.49 & - \\
\hline 37 & Aromadendrene & 1441 & 0.75 & 0.12 & 0.57 & - \\
\hline 38 & $\alpha$-Humulene & 1454 & 0.91 & 0.26 & 1.67 & - \\
\hline 39 & $\gamma$-Gurjunene & 1477 & 0.68 & - & 0.11 & - \\
\hline 40 & Germacrene D & 1485 & 9.55 & 2.35 & 4.51 & - \\
\hline 41 & $\alpha$-Amorphene & 1485 & 0.46 & - & - & 0.12 \\
\hline 42 & $\beta$-Selinene & 1486 & - & - & 1.13 & - \\
\hline 43 & Epi-bicyclosesquiphellandrene & 1489 & 1.17 & - & - & - \\
\hline 44 & Cadina-1,4-diene & 1496 & 0.39 & - & - & - \\
\hline 45 & Bicyclogermacrene & 1500 & 7.93 & 1.32 & 4.19 & - \\
\hline 46 & $\beta$-Bisabolene & 1506 & - & - & 1.96 & 0.24 \\
\hline 47 & $\gamma$-Cadinene & 1514 & - & 0.17 & - & - \\
\hline 48 & Endo-1-bourbonanol & 1522 & 4.24 & 1.67 & 0.12 & - \\
\hline 49 & $\beta$-Maaliene & 1522 & - & 0.10 & - & - \\
\hline 50 & $\delta$-Cadinene & 1525 & 10.69 & 0.89 & 1.37 & - \\
\hline 51 & Nerolidol & 1563 & 1.12 & 0.15 & 4.68 & - \\
\hline 52 & Spathoulenol & 1578 & - & - & 26.89 & - \\
\hline 53 & Caryophyllene oxide & 1583 & - & 0.48 & 0.34 & - \\
\hline 54 & Guaiol & 1601 & - & - & 1.25 & - \\
\hline 55 & $\beta$-Himachalene & 1614 & - & 0.14 & - & - \\
\hline 56 & $\tau$-Muurolol & 1646 & 1.46 & 1.76 & 1.19 & 0.16 \\
\hline 57 & $\beta$-Eudesmol & 1651 & - & 1.58 & 0.31 & 0.29 \\
\hline 58 & $\alpha$-Cadinol & 1654 & 2.55 & - & 2.01 & 0.10 \\
\hline 59 & Bulnesol & 1672 & - & 1.19 & 0.48 & - \\
\hline 60 & Farnesol & 1718 & - & 2.86 & - & - \\
\hline 61 & Farnesyl acetat & 1726 & - & 1.17 & - & - \\
\hline 62 & Benzyl benzoate & 1760 & 1.02 & 1.91 & 0.34 & 0.22 \\
\hline \multirow[t]{7}{*}{63} & Benzyl salicylate & 1866 & 0.19 & 1.25 & - & - \\
\hline & Total & & 96.19 & 96.61 & 98.39 & 98.12 \\
\hline & Monoterpene hydrocarbons & & 9.11 & 51.02 & 3.53 & 30.92 \\
\hline & Oxygenated monoterpenoids & & 1.80 & 15.98 & 0.86 & 66.29 \\
\hline & Sesquiterpene hydrocarbons & & 74.49 & 15.05 & 56.39 & 0.36 \\
\hline & Oxygenated sesquiterpenoids & & 9.37 & 9.69 & 37.27 & 0.55 \\
\hline & Others & & 1.42 & 4.87 & 0.34 & 0.22 \\
\hline
\end{tabular}

a Retention indices on HP-5MS column; ${ }^{\mathbf{b}}$ Standard deviation was insignificant and excluded from the Table to avoid congestion; (-) Not identified.

In this study, 38 compounds were identified from A. xanthioides leaves' essential oil, which accounted for $96.19 \%$ of the total amount of the essential oil (Table 1). The main compounds in the essential oil of leaves are $\beta$-elemene $(31.71 \%), \delta$-cadinene $(10.69 \%)$, germacrene D $(9.55 \%)$, bicycloelemene $(8.12 \%)$, and bicyclogermacrene $(7.93 \%)$. In particular, $\beta$-elemene is a compound reported to be able to fight cancer cells [45-47]. The essential oil from $A$. xanthioides roots was the most abundant, with 43 compounds identified as representing $96.61 \%$ of the total essential oil content (Table 1). The main compounds of the root essential oil are $\beta$-pinene (29.59\%), terpinen-4-ol (10.77\%), and $\alpha$-terpinene (6.96\%). The $\beta$-pinene was reported to have antifungal and antibacterial properties [48]. In addition, it inhibits weed growth through the disruption of membrane integrity as indicated by enhanced peroxidation, electrolyte leakage, and lipoxygenase activity despite the upregulation of peroxidase [49]. For the essential oil of $A$. xanthioides stems, 28 compounds were identified as 
representing $98.39 \%$ of the total essential oil content (Table 1). Similar to the leaf essential oil, $\beta$-elemene is still the main compound with the highest percentage (29.58\%), along with spathulenol (26.89\%) and bicycloelemene $(6.19 \%)$. The spathulenol is sesquiterpene alcohol with the same main frame as azulene. It has antibacterial and antifungal properties along with anti-inflammatory and anti-cancer reactivities [50,51]. It is also considered an inducer of apoptosis. Spathulenol can also be used as a pesticide. In the essential oil of A. xanthioides fruits, only 22 compounds were identified, accounting for $98.12 \%$ of the total essential oil content (Table 1). Bornyl acetate is the most abundant constituent found in the essential oil of fruits $(37.21 \%)$. This is a compound with analgesic and anti-inflammatory effects, especially inhibiting cancer cells' proliferation [52,53]. In addition to bornyl acetate, in the essential oil of fruits, there are other main compounds, including camphor (19.48\%), camphene (14.62\%), and limonene $(9.64 \%)$. Camphor is widely used in traditional and modern medicine for its antibacterial property and its beneficial effects on the cardiovascular system. Furthermore, it has been used as a topical anti-itch, anti-insect, anti-inflammatory, and analgesic treatment [50]. In addition, its low solubility in aqueous solvents makes it an excellent candidate for distribution in nanocarriers [54]. The research by Feng et al. (2019) also showed that the essential oil with two main compounds, bornyl acetate and camphor, were capable of repelling and killing insects [55]. Therefore, the compounds identified in the studied oil samples could play a big role in the essential oil's biological potentials.

There have been some reports on the chemical composition of the essential oil extracted from Amomum species globally. For example, $\beta$-pinene (9.0\%), caryophyllene oxide $(6.6 \%)$, $\beta$-bisabolene (6.4\%), and $\delta$-cadinene (6.2\%) are the main compounds of the essential oil of $A$. cannicarpum leaves [56]. The main compounds identified in the essential oil of A. subulatum leaves are 1,8-cineole (39.8\%) and $\alpha$-terpineol (11.5\%) [21]. The research of Singtothong et al. (2013) identified that camphor (17.6\%), $\alpha$-bisabolol (16.0\%), camphene $(8.2 \%)$, and $\alpha$ humulene $(5.1 \%)$ were the main compounds in the essential oil of A. biflorum [57]. Those of the essential oil from A. villosum fruits are bornyl acetate (51.6\%), camphor (19.8\%), camphene (8.9\%), and limonene (6.2\%) [58]. For the essential oil of A. tsao-ko fruits, the main compounds are 1,8-cineole $(45.24 \%)$, $\rho$-propylbenzaldehyde $(6.04 \%)$, geraniol $(5.11 \%)$, geranial (4.52\%), $\alpha$-terpineol (3.59\%), and $\alpha$-phellandrene (3.07\%) [59]. However, we have not found complete reports on the essential oil's chemical composition of $A$. xanthioides leaves, stems, and roots in the world. We have only recorded a few reports on the essential oil's composition of $A$. xanthioides fruits from China [34,35]. The results obtained in this study, for the essential oil of A. xanthioides fruits, were consistent with the study of Ao et al. (2019) that bornyl acetate and camphor were two main compounds in the fruit essential oil [34]. Compared with the study of Ao et al. (2019), the concentrations of bornyl acetate and camphor in our fruit essential oil were lower. As highlighted previously, this difference can be attributed to growth, genetics, and environmental factors [60].

In particular, we have found some reports on the chemical composition of $A$. xanthioides essential oil in Central Vietnam [36,37]. However, our study samples were collected from Northern Vietnam. This leads to a clear difference between the concentration and composition of the essential oil previously reported and those from the current study. Specifically, the previously reported essential oil of A. xanthioides leaves, roots, and stems from Pu Mat National Park (Central Vietnam) was identified as containing 34, 41, and 25 compounds, respectively [36]. There are compounds found in the essential oil of $A$. xanthioides from $\mathrm{Pu}$ Mat National Park but not found in our essential oil sample and vice versa. For 
example, our study sample's essential leaf oil further identified compounds including $\alpha$-thujene, $\alpha$-terpineol, bornyl acetate, $\alpha$-cubebene, benzyl salicylate but no phytol compounds. Along with that, the concentration of compounds in our essential oil samples was different from that of $A$. xanthioides essential oil samples collected from Pu Mat National Park. The essential oil of A. xanthioides fruits from A Luoi - Thua Thien Hue (Central Vietnam) was identified as containing 15 compounds, with bornyl acetate (27.26\%), camphor (23.73\%), endo-borneol (13.78\%), camphene (11.62\%), D-limonene (10.96\%), and $\beta$-myrcene $(6.17 \%)$ as the main ones [37]. Compared with the essential oil of $A$. xanthioides fruits from A Luoi - Thua Thien Hue, our study has identified 9 new compounds (tricyclene, 1,8-cineole, $\gamma$-terpinene, $\alpha$ amorphene, $\beta$-bisabolene, $\tau$-muurolol, $\beta$-eudesmol, $\alpha$-cadinol, and benzyl benzoate) presenting in the essential oil of $A$. xanthioides fruits, but there has been no compound of (+)-3-carene and geraniol. Along with that, bornyl acetate is also the most abundant compound. It has a higher concentration than the fruit essential oil from A Luoi - Thua Thien Hue with 37.21\%. Again, changes in habitat and climate can affect the composition of the harvested products. As growth and development stages, farming, and genetic characteristics can change significantly $[40,43,60]$.

\section{Conclusions}

Our research on A. xanthioides essential oil collected from Northern Vietnam showed a high variation in the chemical composition of oils extracted from different organs. The highest essential oil yield was recorded for fruits. The compounds found in the essential oil of leaves and stems are mainly sesquiterpene (83.86-93.66\%). Those found in roots and fruits are mainly monoterpene (67.00-97.21\%). The composition and the concentration of the essential oil found in this study are different from those of Amomum plants collected in Vietnam or elsewhere in the world. This difference may be due to several factors such as environmental conditions and climate at the collection site, time of collection, as well as the age and nature of plants.

\section{Funding}

This research received no external funding.

\section{Acknowledgments}

The authors would like to thank the anonymous reviewers for their thoughtful comments and efforts towards improving our manuscript. The authors also thank the Ministry of Science and Higher Education of the Russian Federation for providing Bui Bao Thinh a scholarship.

\section{Conflicts of Interest}

The authors declare no conflict of interest.

\section{References}

1. Boer, H.d.; Newman, M.; Poulsen, A.D.; Droop, A.J.; Fér, T.; Thu Hiền, L.T.; Hlavatá, K.; Lamxay, V.; Richardson, J.E.; Steffen, K.; Leong-Škorničková, J. Convergent morphology in Alpinieae (Zingiberaceae): Recircumscribing Amomum as a monophyletic genus. Taxon 2018, 67, 6-36, https://doi.org/10.12705/671.2.

2. Boonma, T.; Saensouk, S.; Saensouk, P. Amomum foetidum (Zingiberaceae), a new species from Northeast Thailand. Taiwania 2020, 65, 364-370, https://doi.org/10.6165/tai.2020.65.364. 
3. Ding, H.-B.; Yang, B.; Maw, M.B.; Win, P.P.; Tan, Y.-H. Taxonomic studies on Amomum Roxburgh s.l. (Zingiberaceae) in Myanmar II: one new species and five new records for the flora of Myanmar. PhytoKeys 2020, 138, 139-153, https://doi.org/10.3897/phytokeys.138.38736.

4. Ding, H.-B.; Zhou, S.-S.; Yang, B.; Li, R.; Maw, M.B.; Maung, K.W.; Tan, Y.-H. Taxonomic studies on Amomum Roxburgh sl (Zingiberaceae) in Myanmar I: Two new species and two new records for the flora of Myanmar. Phytotaxa 2019, 418, 158-170, https://doi.org/10.11646/phytotaxa.418.2.2.

5. Saha, K.; Sinha, R.K.; Sinha, S. Distribution, Cytology, Genetic Diversity and Molecular phylogeny of selected species of Zingiberaceae - A Review. Feddes Repertorium 2020, 131, 58-68, https://doi.org/10.1002/fedr.201900013.

6. Valukattil Ponnachan, T.; Mamiyil, S.; Vettathukattil Abdul Gafoor Muhammed, N. A New species of Amomum Roxb. (Zingiberaceae) from Nagaland, India. Taiwania 2019, 64, 9-12, https://doi.org/10.6165/tai.2019.64.9.

7. Thomas, V.P.; Dan, M.; Sabu, M.; Jabbar, M.A. Amomum andamanicum (Zingiberaceae): a new species from the Andaman Islands, India. Blumea-Biodiversity, Evolution and Biogeography of Plants 2010, 55, 295-299, https://doi.org/10.3767/000651910X550954.

8. Syazana, S.A.; Meekiong, K.; Afifah, N.; Syauqina, M.Y. Amomum bungoensis: A New Species of Amomum (Zingiberaceae) from Sarawak, Malaysia. Journal of Botany 2018, 2018, 1-5, https://doi.org/10.1155/2018/1978607.

9. Thomas, V.P.; Nissar, V.A.M.; Sabu, M. Amomum kingii var. oblongum (Zingiberaceae): a new variety from Sikkim Himalaya. Phytotaxa 2015, 220, 89-94, https://doi.org/10.11646/phytotaxa.220.1.9.

10. Le, T.H.; Tran, T.B.; Nguyen, Q.B. Utilization pattern of genera Alpinia and Amomum (Zingiberaceae) in North Central Vietnam. Proceedings of the 6th National Scientific Conference of Ecology and Biological Resources (Hanoi, Vietnam) 2015, 1150-1154.

11. Nair, K.P. Large Cardamom (Amomum subulatum Roxb.). In The Geography of Cardamom (Elettaria cardamomum M.) : The "Queen" of Spices - Volume 2, Nair, K.P., Ed. Springer International Publishing: Cham, 2020; 253-280, https://doi.org/10.1007/978-3-030-54474-4_13.

12. Gudade, B.A.; Chhetri, P.; Deka, T.N.; Gupta, U.; Vijayan, A.K. Large cardamom (Amomum subulatum Roxb): a spice crop with multiple uses. Indian Journal of Arecanut, Spices and Medicinal Plants 2013, 15, 15-17.

13. Feng, X.; Jiang, Z.; Li, R. Research progress in essential oil of natural food spice, Amomum tsao-ko. China Condiment 2009, 40-42.

14. Aneja, K.R.; Joshi, R. Antimicrobial activity of Amomum subulatum and Elettaria cardamomum against dental caries causing microorganisms. Ethnobotanical Leaflets 2009, 2009, 3.

15. Yu, G.-W.; Cheng, Q.; Nie, J.; Wang, X.-J.; Wang, P.; Li, Z.-G.; Lee, M.-R. Microwave Hydrodistillation Based on Deep Eutectic Solvent for Extraction and Analysis of Essential Oil from Three Amomum Species Using Gas Chromatography-Mass Spectrometry. Chromatographia 2018, 81, 657-667, https://doi.org/10.1007/s10337-018-3482-8.

16. Sim, S.; Tan, S.K.; Kohlenberg, B.; Braun, N.A. Amomum tsao-ko-Chinese Black Cardamom: Detailed Oil Composition and Comparison With Two Other Cardamom Species. Nat. Prod. Commun. 2019, 14, 1934578X19857675, https://doi.org/10.1177/1934578X19857675.

17. Bharat, S.; Neeru, V.; Sunil, S. Essential Oil Composition and Anti-scabies Potential of Amomum subulatum Roxb. Leaves. Anti-Infective Agents 2602, 261, https://doi.org/10.2174/2211352517666190919143631.

18. Tangjitjaroenkun, J.; Tangchitcharoenkhul, R.; Yahayo, W.; Supabphol, S.; Sappapan, R.; Supabphol, R. Chemical compositions of essential oils of Amomum verum and Cinnamomum parthenoxylon and their in vitro biological properties. J Herbmed Pharmacol 2020, 9, 223-231, https://doi.org/10.34172/jhp.2020.29.

19. Alam, A.; Singh, V. Composition and pharmacological activity of essential oils from two imported Amomum subulatum fruit samples. Journal of Taibah University Medical Sciences 2020, https://doi.org/10.1016/j.jtumed.2020.10.007.

20. Zhang, L.; Liang, X.; Ou, Z.; Ye, M.; Shi, Y.; Chen, Y.; Zhao, J.; Zheng, D.; Xiang, H. Screening of chemical composition, anti-arthritis, antitumor and antioxidant capacities of essential oils from four Zingiberaceae herbs. Industrial Crops and Products 2020, 149, 112342, https://doi.org/10.1016/j.indcrop.2020.112342.

21. Govindarajan, M.; Rajeswary, M.; Senthilmurugan, S.; Vijayan, P.; Alharbi, N.S.; Kadaikunnan, S.; Khaled, J.M.; Benelli, G. Larvicidal activity of the essential oil from Amomum subulatum Roxb. (Zingiberaceae) against Anopheles subpictus, Aedes albopictus and Culex tritaeniorhynchus (Diptera: Culicidae), and non- 
target impact on four mosquito natural enemies. Physiol. Mol. Plant Pathol. 2018, 101, 219-224, https://doi.org/10.1016/j.pmpp.2017.01.003.

22. Tang, C.; Chen, J.; Zhou, Y.; Ding, P.; He, G.; Zhang, L.; Zhao, Z.; Yang, D. Exploring antimicrobial mechanism of essential oil of Amomum villosum Lour through metabolomics based on gas chromatographymass spectrometry in methicillin-resistant Staphylococcus aureus. Microbiol. Res. 2021, 242, 126608, https://doi.org/10.1016/j.micres.2020.126608.

23. Ujilestari, T.; Martien, R.; Ariyadi, B.; Dono, N.D.; Zuprizal. Antibacterial effects of essential oils of Cymbopogon citratus and Amomum compactum under self-nanoemulsifying drug delivery system (SNEDDS). IOP Conference Series: Earth and Environmental Science 2019, 387, 012071, https://doi.org/10.1088/1755-1315/387/1/012071.

24. Kapoor, I.P.S.; Singh, B.; Singh, G.; Isidorov, V.; Szczepaniak, L. Chemistry, antifungal and antioxidant activities of cardamom (Amomum subulatum) essential oil and oleoresins. International Journal of Essential Oil Therapeutics 2008, 2, 29-40.

25. Satyal, P.; Dosoky, N.S.; Kincer, B.L.; Setzer, W.N. Chemical Compositions and Biological Activities of Amomum subulatum Essential Oils from Nepal. Nat. Prod. Commun. 2012, 7, 1934578X1200700935, https://doi.org/10.1177/1934578X1200700935.

26. Yang, Y.; Yue, Y.; Runwei, Y.; Guolin, Z. Cytotoxic, apoptotic and antioxidant activity of the essential oil of Amomum tsao-ko. Bioresour. Technol. 2010, 101, 4205-4211, https://doi.org/10.1016/j.biortech.2009.12.131.

27. Aungtikun, J.; Soonwera, M. Mosquito-repellent activity of Star anise (Illicium verum Hook. f.), Bustard cardamom (Amomum villosum Lour.) and Best cardamom (Amomum krervanh Pierre.) essential oils against Aedes albopictus (Skuse). Inter. J. Agri. Tech 2020, 16, 19-26.

28. Chen, C.; You, F.; Wu, F.; Luo, Y.; Xu, H.; Liu, Y. Antiangiogenesis Efficacy of Ethanol Extract from Amomum tsaoko in Ovarian Cancer through Inducing ER Stress to Suppress p-STAT3/NF-kB/IL-6 and VEGF Loop. Evid. Based Complement. Alternat. Med. 2020, 2020, 2390125, https://doi.org/10.1155/2020/2390125.

29. Juwitaningsih, T.; Jahro, I.S.; Sari, S.A. Evaluation of North Sumatera Cardamom seed (Amomum compactum) Extract as Antibacterial and Anticancer. Journal of Physics: Conference Series 2020, 1485, 012019, https://doi.org/10.1088/1742-6596/1485/1/012019.

30. Lamxay, V.; Newman, M.F. A revision of Amomum (Zingiberaceae) in Cambodia, Laos and Vietnam. Edinburgh Journal of Botany 2012, 69, 99-206, https://doi.org/10.1017/S0960428611000436.

31. Lee, Y.S.; Kang, M.H.; Cho, S.Y.; Jeong, C.S. Effects of constituents of amomum xanthioides on gastritis in rats and on growth of gastric cancer cells. Arch. Pharmacal Res. 2007, 30, 436-443, https://doi.org/10.1007/BF02980217.

32. Kim, K.H.; Choi, J.W.; Choi, S.U.; Lee, K.R. Terpene glycosides and cytotoxic constituents from the seeds of Amomum xanthioides. Planta Med. 2010, 76, 461-464, https://doi.org/10.1055/s-0029-1186194.

33. Kim, H.-G.; Han, J.-M.; Lee, J.-S.; Suk Lee, J.; Son, C.-G. Ethyl acetate fraction of Amomum xanthioides improves bile duct ligation-induced liver fibrosis of rat model via modulation of pro-fibrogenic cytokines. Sci. Rep. 2015, 5, 14531, https://doi.org/10.1038/srep14531.

34. Ao, H.; Wang, J.; Chen, L.; Li, S.; Dai, C. Comparison of volatile oil between the fruits of Amomum villosum Lour. and Amomum villosum Lour. var. xanthioides TL Wu et Senjen based on GC-MS and chemometric techniques. Molecules 2019, 24, 1663, https://doi.org/10.3390/molecules24091663.

35. Bi-yao, Z.L.-f.L.; Dan, X. Studies on Chemical Constituents of Amomum Essential Oil (1): A. villosum Lour, and A. villosum Lour. var. xanthioides (Wall, ex Bak.) TL Wu.[J]. Guihaia 1983, 8.

36. Dai, D.N.; Huong, L.T.; Chau, L.T.M.; Dung, D.M.; Chung, M.V. Volatile constituents of Amomum xanthioides Wall. ex Baker. Proceedings of the 6th National Scientific Conference of Ecology and Biological Resources (Hanoi, Vietnam) 2015, 1078-1082, http://iebr.ac.vn/database/HNTQ6/1078.pdf.

37. Le, N.N.; Tan, N.T.; Minh, T.N.; Duc, H.V.; Hoai, N.T. Physicochemical properties and chemical composition of the essential oil of Amomum xanthioides from A Luoi - Thua Thien Hue. Journal of Medicine And Pharmacy 2018, 8, 96-101, https://doi.org/10.34071/jmp.2018.4.14.

38. Ascrizzi, R.; Ceccarini, L.; Tavarini, S.; Flamini, G.; Angelini, L.G. Valorisation of hemp inflorescence after seed harvest: Cultivation site and harvest time influence agronomic characteristics and essential oil yield and composition. Industrial Crops and Products 2019, $139, \quad$ 111541, https://doi.org/10.1016/j.indcrop.2019.111541. 
39. Chua, L.Y.W.; Chong, C.H.; Chua, B.L.; Figiel, A. Influence of Drying Methods on the Antibacterial, Antioxidant and Essential Oil Volatile Composition of Herbs: a Review. Food and Bioprocess Technology 2019, 12, 450-476, https://doi.org/10.1007/s11947-018-2227-x.

40. Hendawy, S.F.; Hussein, M.S.; El-Gohary, A.E.; Soliman, W.S. Chemical Constituents of Essential Oil in Chervil (Anthriscus cerefolium L. Hoffm.) Cultivated in Different Locations. Journal of Essential Oil Bearing Plants 2019, 22, 264-272, https://doi.org/10.1080/0972060X.2019.1587316.

41. Ho, P.H. An Illustrated Flora of Vietnam Vol. 3. Ho Chi Minh: Nha Xuat Ban Tre.[In Vietnamese], 2000.

42. Adams, R.P. Identification of essential oil components by gas chromatography/mass spectrometry; Allured publishing corporation Carol Stream, IL: 2007; Vol. 456.

43. Hazrati, S.; Ebadi, M.-T.; Mollaei, S.; Khurizadeh, S. Evaluation of volatile and phenolic compounds, and antioxidant activity of different parts of Ferulago angulata (schlecht.) Boiss. Industrial Crops and Products 2019, 140, 111589, https://doi.org/10.1016/j.indcrop.2019.111589.

44. Mejri, J.; Abderrabba, M.; Mejri, M. Chemical composition of the essential oil of Ruta chalepensis L: Influence of drying, hydrodistillation duration and plant parts. Industrial Crops and Products 2010, 32, 671673, https://doi.org/10.1016/j.indcrop.2010.05.002.

45. Yao, Y.-Q.; Ding, X.; Jia, Y.-C.; Huang, C.-X.; Wang, Y.-Z.; Xu, Y.-H. Anti-tumor effect of $\beta$-elemene in glioblastoma cells depends on p38 MAPK activation. Cancer Lett. 2008, 264, 127-134, https://doi.org/10.1016/j.canlet.2008.01.049.

46. Wang, G.; Li, X.; Huang, F.; Zhao, J.; Ding, H.; Cunningham, C.; Coad, J.E.; Flynn, D.C.; Reed, E.; Li, Q.Q. Antitumor effect of $\beta$-elemene in non-small-cell lung cancer cells is mediated via induction of cell cycle arrest and apoptotic cell death. Cellular and Molecular Life Sciences CMLS 2005, 62, 881-893, https://doi.org/10.1007/s00018-005-5017-3.

47. Li, Q.Q.; Wang, G.; Huang, F.; Banda, M.; Reed, E. Antineoplastic effect of $\beta$-elemene on prostate cancer cells and other types of solid tumour cells. J. Pharm. Pharmacol. 2010, 62, 1018-1027, https://doi.org/10.1111/j.2042-7158.2010.01135.x.

48. Silva, A.C.R.d.; Lopes, P.M.; Azevedo, M.M.B.d.; Costa, D.C.M.; Alviano, C.S.; Alviano, D.S. Biological activities of a-pinene and $\beta$-pinene enantiomers. Molecules 2012, 17, 6305-6316, https://doi.org/10.3390/molecules17066305.

49. Chowhan, N.; Singh, H.P.; Batish, D.R.; Kaur, S.; Ahuja, N.; Kohli, R.K. $\beta$-Pinene inhibited germination and early growth involves membrane peroxidation. Protoplasma 2013, 250, 691-700, https://doi.org/10.1007/s00709-012-0446-y.

50. Ghavam, M.; Manca, M.L.; Manconi, M.; Bacchetta, G. Chemical composition and antimicrobial activity of essential oils obtained from leaves and flowers of Salvia hydrangea DC. ex Benth. Sci. Rep. 2020, 10, 15647, https://doi.org/10.1038/s41598-020-73193-y.

51. do Nascimento, K.F.; Moreira, F.M.F.; Alencar Santos, J.; Kassuya, C.A.L.; Croda, J.H.R.; Cardoso, C.A.L.; Vieira, M.d.C.; Góis Ruiz, A.L.T.; Ann Foglio, M.; de Carvalho, J.E.; Formagio, A.S.N. Antioxidant, antiinflammatory, antiproliferative and antimycobacterial activities of the essential oil of Psidium guineense Sw. and spathulenol. J. Ethnopharmacol. 2018, 210, 351-358, https://doi.org/10.1016/j.jep.2017.08.030.

52. Wu, X.; Li, X.; Xiao, F.; Zhang, Z.; Xu, Z.; Wang, H. Studies on the analgesic and anti-inflammatory effect of bornyl acetate in volatile oil from Amomum villosum. Zhong yao cai $=$ Zhongyaocai $=$ Journal of Chinese medicinal materials 2004, 27, 438-439.

53. Karan, T.; Yildiz, I.; Aydin, A.; Erenler, R. Inhibition of various cancer cells proliferation of bornyl acetate and essential oil from Inula graveolens (Linnaeus) Desf. Records of Natural Products 2018, 12, http://doi.org/10.25135/rnp.30.17.09.057.

54. Manconi, M.; Petretto, G.; D’hallewin, G.; Escribano, E.; Milia, E.; Pinna, R.; Palmieri, A.; Firoznezhad, M.; Peris, J.E.; Usach, I.; Fadda, A.M.; Caddeo, C.; Manca, M.L. Thymus essential oil extraction, characterization and incorporation in phospholipid vesicles for the antioxidant/antibacterial treatment of oral cavity diseases. Colloids Surf. B. Biointerfaces 2018, 171, 115-122, https://doi.org/10.1016/j.colsurfb.2018.07.021.

55. Feng, Y.-X.; Wang, Y.; Chen, Z.-Y.; Guo, S.-S.; You, C.-X.; Du, S.-S. Efficacy of bornyl acetate and camphene from Valeriana officinalis essential oil against two storage insects. Environmental Science and Pollution Research 2019, 26, 16157-16165, https://doi.org/10.1007/s11356-019-05035-y.

56. Mathew, J.; Sabulal, B.; George, V.; Dan, M.; Shiburaj, S. Chemical Composition and Antimicrobial Activity of the Leaf Oil of Amomum cannicarpum (Wight) Bentham ex Baker. J. Essent. Oil Res. 2006, 18, 35-37, https://doi.org/10.1080/10412905.2006.9699379. 
57. Singtothong, C.; Gagnon, M.J.; Legault, J. Chemical Composition and Biological Activity of the Essential Oil of Amomum biflorum. Nat. Prod. Commun. 2013, 8, https://doi.org/10.1177/1934578X1300800234.

58. Chen, Z.-y.; Guo, S.-s.; Cao, J.-q.; Pang, X.; Geng, Z.-f.; Wang, Y.; Zhang, Z.; Du, S.-s. Insecticidal and repellent activity of essential oil from Amomum villosum Lour. and its main compounds against two storedproduct insects. Int. J. Food Prop. 2018, 21, 2265-2275, https://doi.org/10.1080/10942912.2018.1508158.

59. Yang, Y.; Yan, R.-W.; Cai, X.-Q.; Zheng, Z.-L.; Zou, G.-L. Chemical composition and antimicrobial activity of the essential oil of Amomum tsao-ko. J. Sci. Food Agric. 2008, 88, 2111-2116, https://doi.org/10.1002/jsfa.3321.

60. Tsusaka, T.; Makino, B.; Ohsawa, R.; Ezura, H. Genetic and environmental factors influencing the contents of essential oil compounds in Atractylodes lancea. PLoS One 2019, 14, e0217522, https://doi.org/10.1371/journal.pone.0217522. 